\title{
IMPACT OF POLLUTION AND TILT ANGLE ON SOLAR PHOTOVOLTAIC MODULES PERFORMANCE*
}

\author{
Andi Hida, Rajmonda Bualoti, Marialis Çelo \\ Faculty of Electrical Engineering, Polytechnic University of Tirana, \\ Square "Mother Teresa" 4, Tirana, Albania \\ andi.hida@fie.upt.al
}

\begin{abstract}
A b s t r a c t: Taking into account the substantial cost of a photovoltaic (PV) system, should maximise module efficiency. The experimental tests are conducted with the group of 10 photovoltaic panels installed on the roof of the building of the Electrical Engineering Faculty resided on the Polytechnic University of Tirana. The PV panels are split in groups of two with 5 different tilt angles, respectively $0^{\circ}, 30^{\circ}, 45^{\circ}, 60^{\circ}$ and $90^{\circ}$. To view the pollution and the tilt angle effects, one of the panels is cleaned every day. Monitoring the group of panels gives interesting conclusion about the impact of the dust and the tilt angle on PV production efficiency, as well as, the impact of the tilt angle to the dust settlement. The results show an increase in the performance of clean panel. The I-V and P-V characteristics curves were constructed and compared.
\end{abstract}

Key words: photovoltaic module; dust; module performance; tilt angle; I-V characteristics

\section{ВЛИЈАНИЕ НА ЗАГАДУВАЊЕТО И НА АГОЛОТ НА НАКЛОНОТ ВРЗ ПЕРФОРМАНСИТЕ НА ФОТОВОЛТАИЧНИТЕ МОДУЛИ}

\begin{abstract}
А п с т р а к т: Со оглед на високата цена на фотоволтаичните (ФВ) системи, потребно е да се максимизира енергетското производство од модулите. Експериментални испитувања се направени на група од 10 фотоволтаични модули инсталирани на покривот на зградата на Факултетот за електротехника при Политехничкиот универзитет во Тирана. ФВ-панели беа инсталирани по два во пет групи со пет различни агли на наклон: $0^{\circ}, 30^{\circ}, 45^{\circ}, 60^{\circ}$ and $90^{\circ}$. За да се утврди влијанието на таложењето на прав и на аголот на наклонот, едниот од модулите се чистеше секој ден. Со мониторинг на енергетското производство на групите се добиени интересни заклучоци во однос на влијанието на таложењето на прав и на аголот на наклонот. Резултатите покажаа зголемено производство кај чистите модули. Конструирани и споредени се кривите на I-V и P-V-карактеристики на ФВ-панелите.
\end{abstract}

Клучни зборови: фотоволтаичен модул; прав; перформанси на модули; агол на наклон; I-V карактеристика

\section{INTRODUCTION}

Interest on renewable energy sources, everywhere in the world, is increasing day by day for these reasons: oil, natural gas and coal are all with limited reserves, fuel stocks (especially oil) are concentrated (nearly $75 \%$ of them) in the Middle East area, a zone of high volatility, and more weight at the present time is the ever-increasing environmental pollution. [1]

It is now apparent that among renewable energy sources, solar energy is a very promising source of energy for the future and its use is quite attractive [2].

High power capacity per unit weight, silent operation, no need for an active cooling system, and easy installation are the main advantages of PV technology [3]. The average lifetime of photovoltaic panels is about 25 to 30 years. [4]

The radiation received by cells inside the PV module is lower than radiation arriving to the module surface. The main causes of this energy loss are dirt accumulation on the surface of the modules and reflection and absorption losses by the materials

\footnotetext{
* Extended version of the manuscript published in the Proceedings of the $10^{\text {th }}$ MAKO CIGRE Conference, Ohrid, September $24-26$, 2017 (Проширена верзија од трудот објавен во Зборникот на трудови од 10. Советување на МАКО СИГРЕ, Охрид, 24-26 септември 2017).
} 
covering the cells [5]. On a fixed tilt module, the soiling effect increases as the tilt angle decreases.

Energy loss of $50 \%$ from PV system due to soiling has been reported in places like Iraq and Libya. Hence, energy yield loss due to soiling is an important parameter to be considered, and is dependent on the geographical location [6].

The paper presents the impact of the dust and the tilt angle on PV production efficiency. The results show an increase in the performance of clean panel. For this reason, it is necessary to remove the dust by programming the periodic cleaning of the modules. The most common method of cleaning PV modules in the field is using water. But, if the water available for cleaning at the site is hard, it would result in damaging the module glass surface. [7-8]

\section{SOLAR ENERGY IN ALBANIA}

The geographic position of Albania and its Mediterranean climate provide favorable conditions for the successful development of the solar energy. The high intensity of solar radiation and its duration, temperature and air humidity, etc., will contribute to this. The Mediterranean climate with mild winters and hot and dry summers make Albania a country with higher potential for utilization of solar energy than the average (Figure 1).

Currently only hydropower makes a significant contribution to the current energy consumption in Albania. The present power system meets only $70-80 \%$ of the total demand. However, the country has significant potential for renewable resources in the form of wind, solar and biomass. It can be said that the main challenges of the Albanian energy sector are diversification of energy resources and selfsufficiency of domestic energy needs, thus reducing dependence on imports.

According to the measurements on the solar radiation carried out by the Hydrometeorological Institute that are based on the data of nine meteorological stations, under the conditions of the geographic belt where the meteorological stations are located, the total annual solar radiation varies from a minimum of $1,185 \mathrm{kWh} / \mathrm{m}^{2}$ in the north-eastern part of Albania (Kukesi) to a maximum of $1,690 \mathrm{kWh} / \mathrm{m}^{2}$ in the south-western part of Albania (Fieri). So, the average annual solar radiation in Albania is 1,450 $\mathrm{kWh} / \mathrm{m}^{2}[9]$.

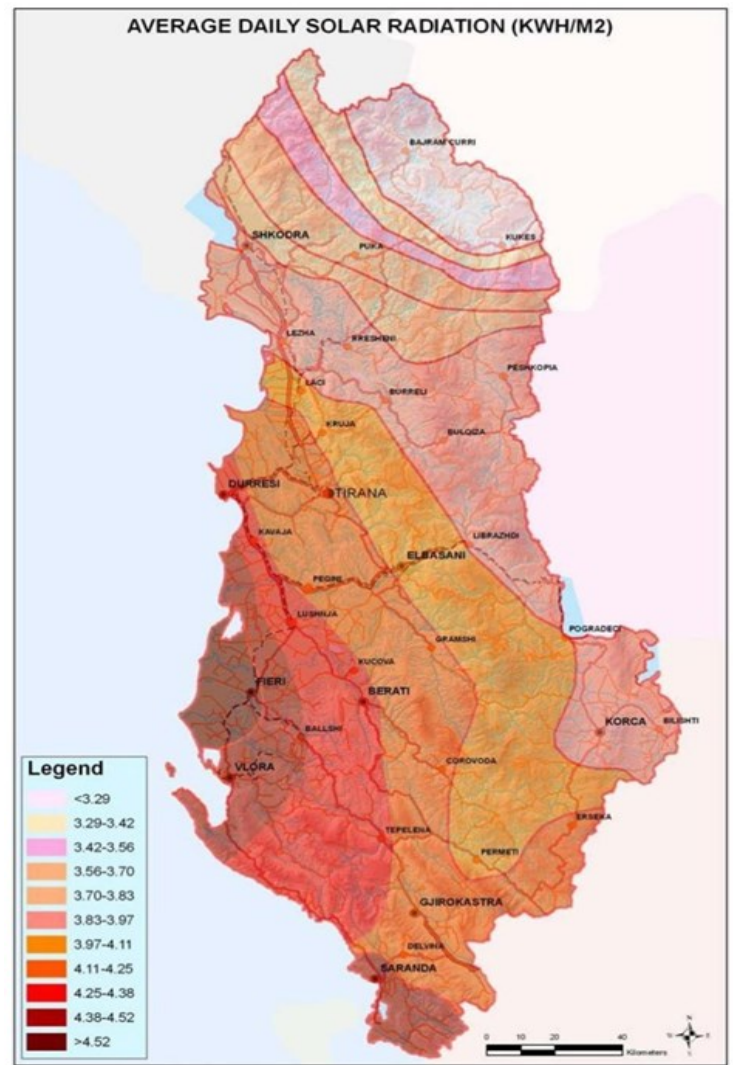

Fig. 1. Average daily solar radiation and average quantity of sunshine hours in Albania 
In addition, from the same measurements appears that the average daily solar radiation varies between $3.2 \mathrm{kWh} / \mathrm{m}^{2}$ per day in the north-eastern part of Albania (Kukesi) and $4.6 \mathrm{kWh} / \mathrm{m}^{2}$ per day in the south-western part of Albania (Fieri). The average daily solar radiation for the whole country is 4.3 $\mathrm{kWh} / \mathrm{m}^{2}$ per day. Most areas of the Albania benefit more than 2,200 hours of sunshine per year, while the average for the whole country is about 2,400 hours of sunshine/year. The western part of Albania receives more than 2,500 hours of sunshine/year, while in Fieri 2,850 hours of sunshine/year have been recorded. The number of sunny days varies from an average of 240-260 days/year to a maximum of 280-300 days/year, in the south-western part of Albania.

The Table 1 gives the average solar radiation intensity for the six main Albanian meteorological stations and for each month of the year. These data are obtained from the Institute of Hydrometeorology.

\section{Table 1}

The solar radiation intensity $\mathrm{kWh} / \mathrm{m}^{2}$ per day

\begin{tabular}{lcccccc}
\hline \hline Month & \multicolumn{3}{c}{ Shkoder } & Peshkopi & \multicolumn{3}{c}{ Tirane } & \multicolumn{5}{c}{ Vlore } & Erseke & Sarande \\
\hline January & 1,70 & 1,55 & 1,80 & 2,15 & 1,90 & 1,9 \\
February & 2,30 & 2,30 & 2,50 & 2,85 & 2,70 & 2,4 \\
March & 3,35 & 3,25 & 3,40 & 3,9 & 3,40 & 3,6 \\
April & 4,50 & 4,15 & 4,20 & 5,00 & 4,40 & 4,8 \\
May & 5,45 & 5,25 & 5,55 & 6,05 & 5,60 & 5,8 \\
June & 6,10 & 5,85 & 6,40 & 6,80 & 6,40 & 6,8 \\
July & 6,50 & 6,25 & 6,70 & 7,20 & 6,80 & 6,1 \\
August & 5,55 & 5,45 & 6,05 & 6,40 & 5,90 & 4,8 \\
September & 4,45 & 4,35 & 4,70 & 5,15 & 4,70 & 3,6 \\
October & 2,90 & 2,90 & 3,20 & 3,50 & 3,10 & 3,2 \\
November & 2,10 & 1,85 & 2,15 & 2,40 & 2,10 & 2,0 \\
December & 1,70 & 1,50 & 1,75 & 1,85 & 1,80 & 1,8 \\
\hline \hline
\end{tabular}

\section{PHOTOVOLTAIC CELLS}

\section{The characteristic curve of the equivalent circuit}

A solar panel consists of individual cells that are large-area semiconductor diodes, constructed so that light can penetrate into the region of the $p-n$ junction. The junction formed between the n-type silicon wafer and the p-type surface layer governs the diode characteristics as well as the photovoltaic effect.
Light is absorbed in the silicon, generating both excess holes and electrons. These excess charges can flow through an external circuit to produce power.

For modeling the PV solar panel the one-diode model was used to describe the electrical characteristics of the solar cell (Figure 2). The model consists of a linear independent current source in parallel to a diode, a series $\left(R_{s}\right)$, and a shunt resistance $\left(R_{s h}\right)$, as shown in Figure 3 [10].

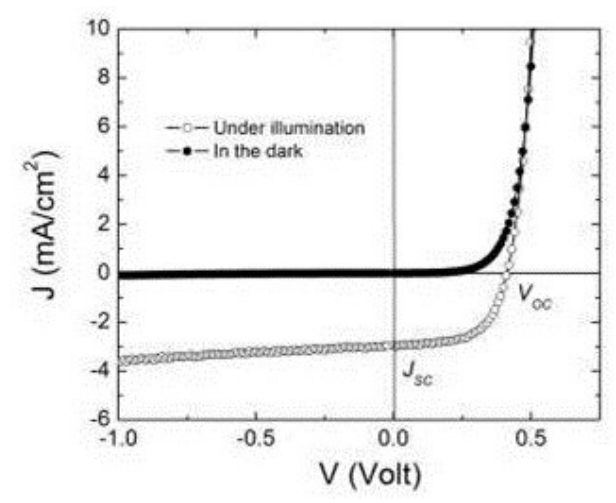

Fig. 2. Shift of the solar cell I/V curve with increasing incident light

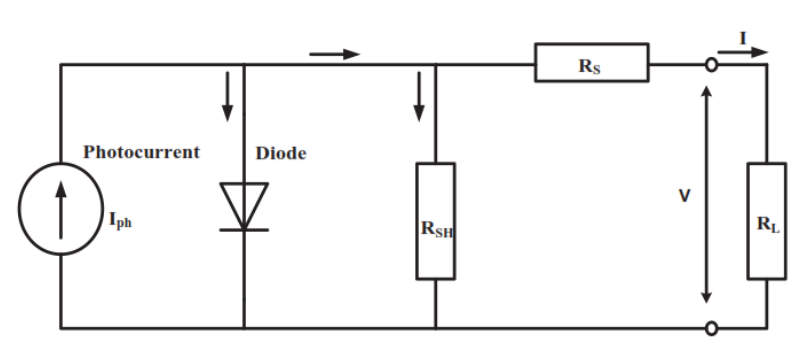

Fig. 3. Cell equivalent circuit (one-exponential model)

The main expression for determining the general one-diode model is written as given below:

$$
I=I_{p h}-I_{0}\left[\exp \left(\frac{q V+I R_{s}}{\gamma_{k} N_{c s} T}\right)-1\right]-\frac{V+I R_{s}}{R_{s h}},
$$

where " $\Gamma$ " is the current supplied by the module (A), " $I_{0}$ " is the inverse saturation current, depending on the temperature (A), and " $I_{p h}$ " is the photocurrent (A) proportional to the irradiance $G$, with a correction as a function of $T_{C}$, the effective temperature of the cells $(\mathrm{K})$, " $q$ " is the charge of the electron (= $1.602 \times 10-19 \mathrm{C}$ ) and " $V$ " is the voltage at the terminals of the module (V). $N_{c s}$, Gamma, and " $k$ " are the number of cells in series, the diode quality factor normally between 1 and 2, and Boltzmann's con$\operatorname{stant}\left(=1.381 \times 10^{23} \mathrm{~J} / \mathrm{K}\right)$, respectively. 
Every model of solar panel has unique performance characteristics which can be graphically represented in a chart. The graph is called an "I-V curve", and it refers to the module's output relationship between current (I) and voltage (V) (Figure 4) [11].

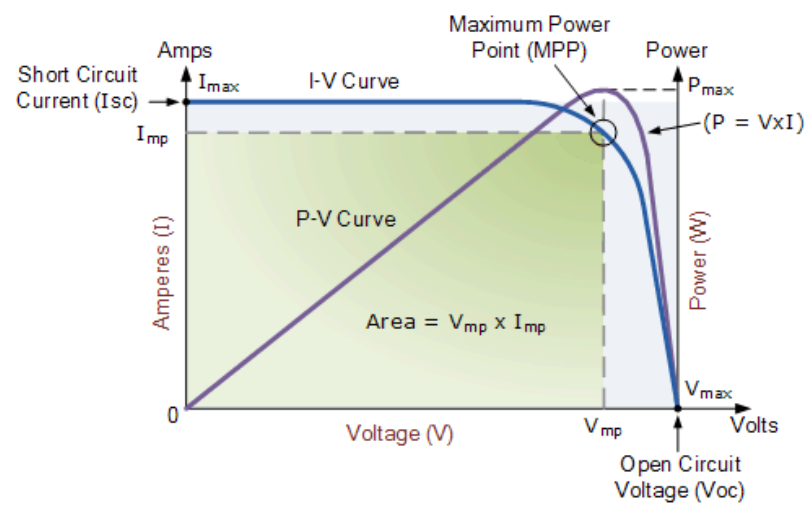

Fig. 4. Solar cell I-V characteristic curve

Because of Ohm's law (and the equation Power $=$ Voltage $\times$ Current), the result of reduced voltage is reduced power output. The ideal position on any I-V curve - the sweet spot where we can collect the most power from the module - is at the "knee". That's the maximum power point (MPP).

\section{Photovoltaic cell efficiency}

The characteristic resistance of a solar cell is the output resistance of the solar cell at its maximum power point. If the resistance of the load is equal to the characteristic resistance of the solar cell, then the maximum power is transferred to the load and the solar cell operates at its maximum power point.

$$
L_{m}=\frac{V_{m p}}{I_{m p}}
$$

The efficiency is the most commonly used parameter to compare the performance of one solar cell to another. Efficiency is defined as the ratio of energy output from the solar cell to input energy from the sun.

The efficiency of a solar cell is determined as the fraction of incident power which is converted to electricity and is defined as:

$$
\begin{gathered}
\eta=\frac{V_{o c} \cdot I_{s c} \cdot F F}{P_{i n}} \\
P_{\max }=V_{o c} \cdot I_{s c} \cdot F F \\
F F=\frac{V_{m p} \cdot I_{m p}}{V_{o c} \cdot I_{s c}}
\end{gathered}
$$

where:

$V_{o c}$ is the open-circuit voltage;

$I_{s c}$ is the short-circuit current;

$F F$ is the fill factor and $\eta$ is the efficiency.

The input power for efficiency calculations is $1 \mathrm{~kW} / \mathrm{m}^{2}$ or $100 \mathrm{~mW} / \mathrm{cm}^{2}$. Thus the input power for a $100 \times 100 \mathrm{~mm}^{2}$ cell is $10 \mathrm{~W}$ and for a $156 \times 156$ $\mathrm{mm}^{2}$ cell is $24.3 \mathrm{~W}$.

To increase the efficiency of the solar cell it is necessary to increase $V_{o c}$ and $I_{s c}$ and that $F F$ is around one [12].

\section{EXPERIMENTAL WORK}

The experimental tests are conducted with the group of 10 photovoltaic panels installed on the roof of the building of the Electrical Engineering Faculty resided on the Polytechnic University of Tirana (Figure 5).

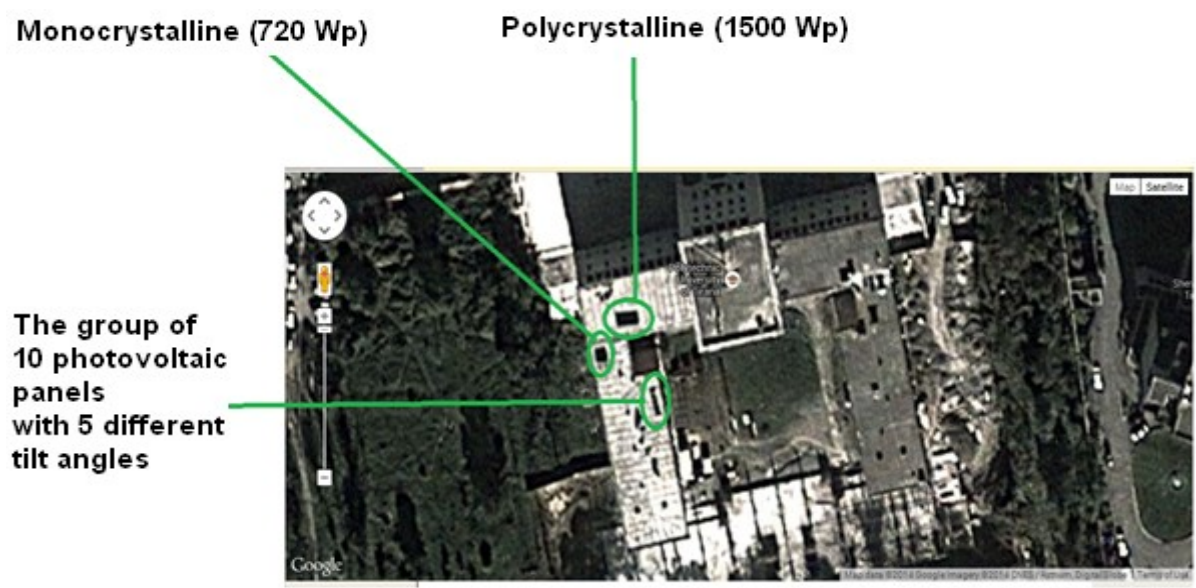

Fig. 5. The roof of the building of the Polytechnic University of Tirana 
The cells type is ISF-60/12 (maximum power of each panel is $60 \mathrm{Wp}$, made by Isofoton, Spain (Table 2).

The installation of PV panels are split in groups of two with 5 different tilt angles, respectively $0^{\circ}, 30^{\circ}, 45^{\circ}, 60^{\circ}$ and $90^{\circ}$ (Figure 6). To view the dust and the tilt angle effects, one of the panels is cleaned every day.

For each panel open circuit voltage and short circuit current are measured, parameters that affect solar panel efficiency.

To construct characteristic curves I-V (voltage-current) and P-V (power-voltage), a rheostat is used and current and voltage values are measured as shown below (Figure 7).
Table 2

The used PV modules specifications

\begin{tabular}{ll}
\hline \hline Solar module type & ISF-60/12 \\
\hline Peak power & $60 \mathrm{~W}$ \\
Max. power voltage & $17.3 \mathrm{~V}$ \\
Max. power current & $3.47 \mathrm{~A}$ \\
Open-circuit voltage & $21.6 \mathrm{~V}$ \\
Short-circuit current & $3.73 \mathrm{~A}$ \\
Weight & $6.5 \mathrm{~kg}$ \\
Dimensions & $776 \times 662 \times 39,5 \mathrm{~mm}$ \\
Panel efficiency & $11.7 \%$ \\
Fill factor & $74.5 \%$ \\
\hline \hline
\end{tabular}

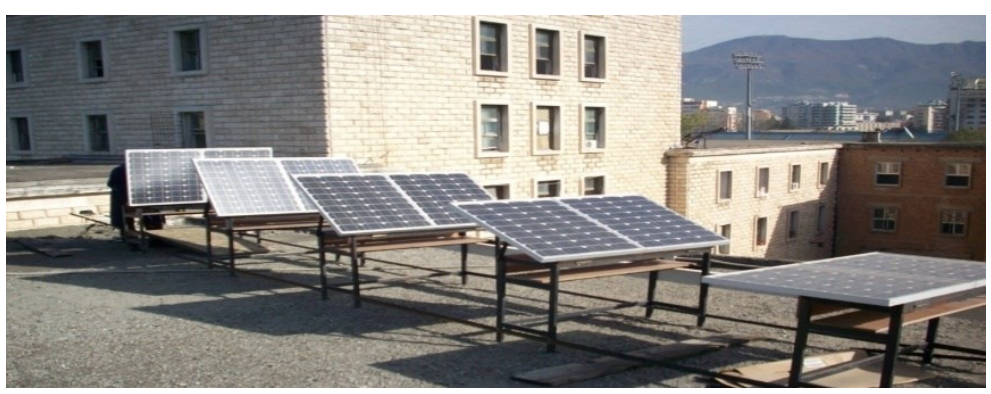

Fig. 6. Panels with different tilt angles
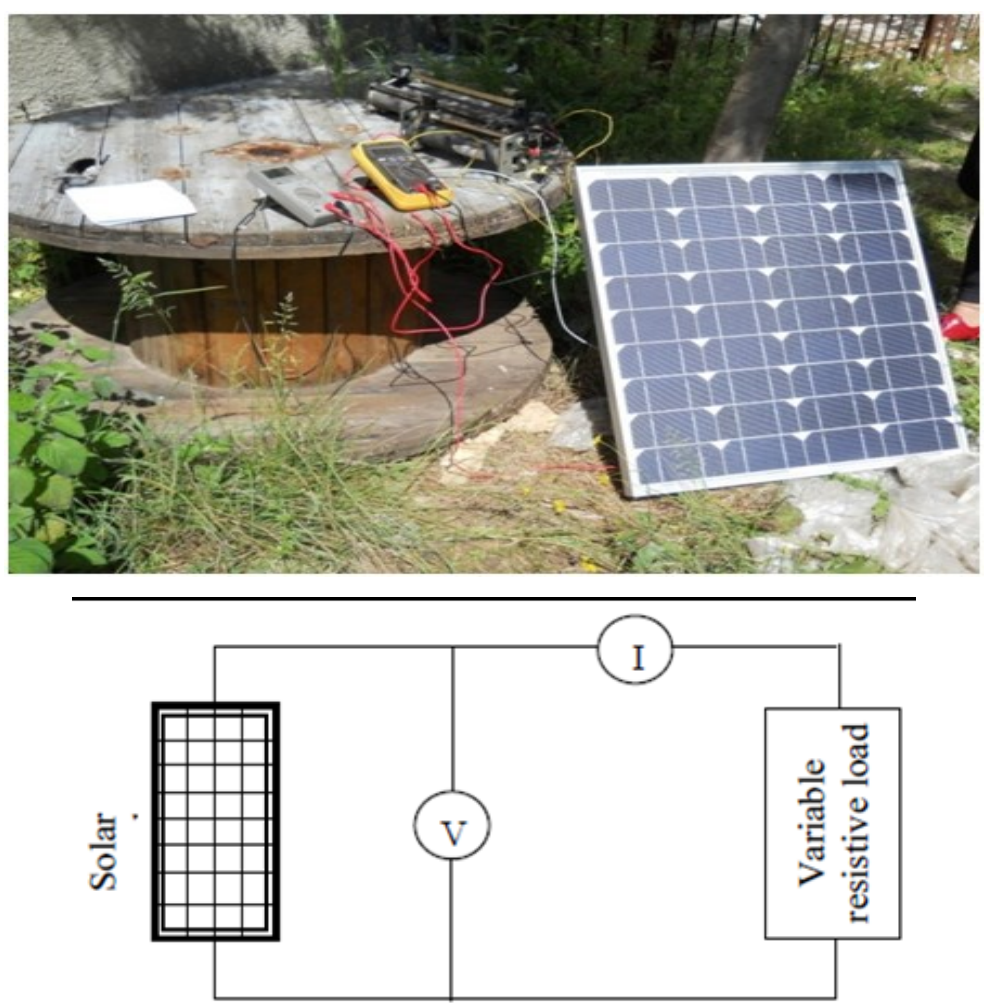

Fig. 7. Test I-V and P-V characteristics for a photovoltaic module 


\section{RESULTS AND DISCUSSION}

For photovoltaic panels with $0^{\circ}$ and $45^{\circ}$ tilt angles, tested with load, the volt-ampere characteristics built for the clean and polluted panel case (Figure 8).

The figure curves clarify that the cleaned cell produced the maximum current and voltage while the polluted one produced the minimum I-V.

It appears that pollution affect both characteristic curves $\mathrm{I}-\mathrm{V}$, but rather to affect the angle $0^{\circ}$. This is due to the placement of the panel horizontally, making it difficult to remove pollution in case of rainfall or winds. It should be noted that the pollution deposited on the lower parts of the modules near the frames (which should be taken into account for cleaning more often).

This impact of pollution is also evident in the characteristic curves $\mathrm{P}-\mathrm{V}$ constructed from the data obtained at the I-V curves (Figure 9):
From the calculations it turns out that the difference in relation to the maximum power $\left(P_{\max }\right)$ for the $0^{\circ}$ tilt angle is $12.9 \%$, whereas for the $45^{\circ}$ is $8 \%$.

It is thus seen that the efficiency of the solar cell depends on open circuit voltage and short-circuit current.

The open circuit voltages are measured for each tilt angle in 3 different times, to see the impact of the pollution in each case. By means of measured values the differences in $\%$ of the open circuit voltages are extracted as follows Tables 3 and 4 .

From these data it is seen that the greatest influence on the open circuit in relation to pollution is on $0^{\circ}$ solar panel. While the smallest impact of pollution is on the $90^{\circ}$ solar panel.

The same thing can be said about the short circuit current. The data measured in this case are presented in the Table 5.

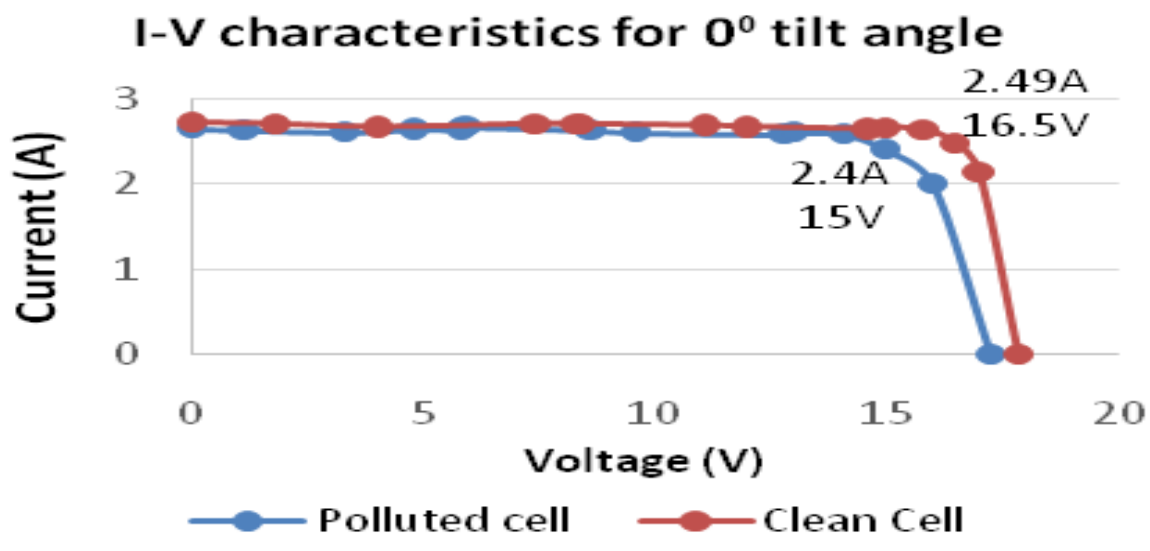

\section{I-V characteristics for $45^{\circ}$ tilt angle}

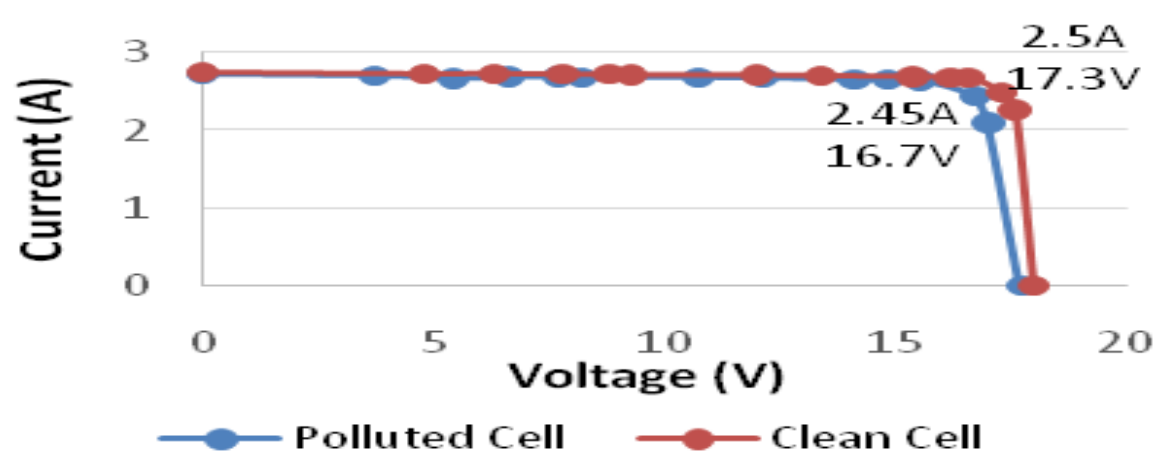

Fig. 8. I-V characteristics for the tested PV cells with load (for $0^{\circ}$ and $45^{\circ}$ tilt angle) 

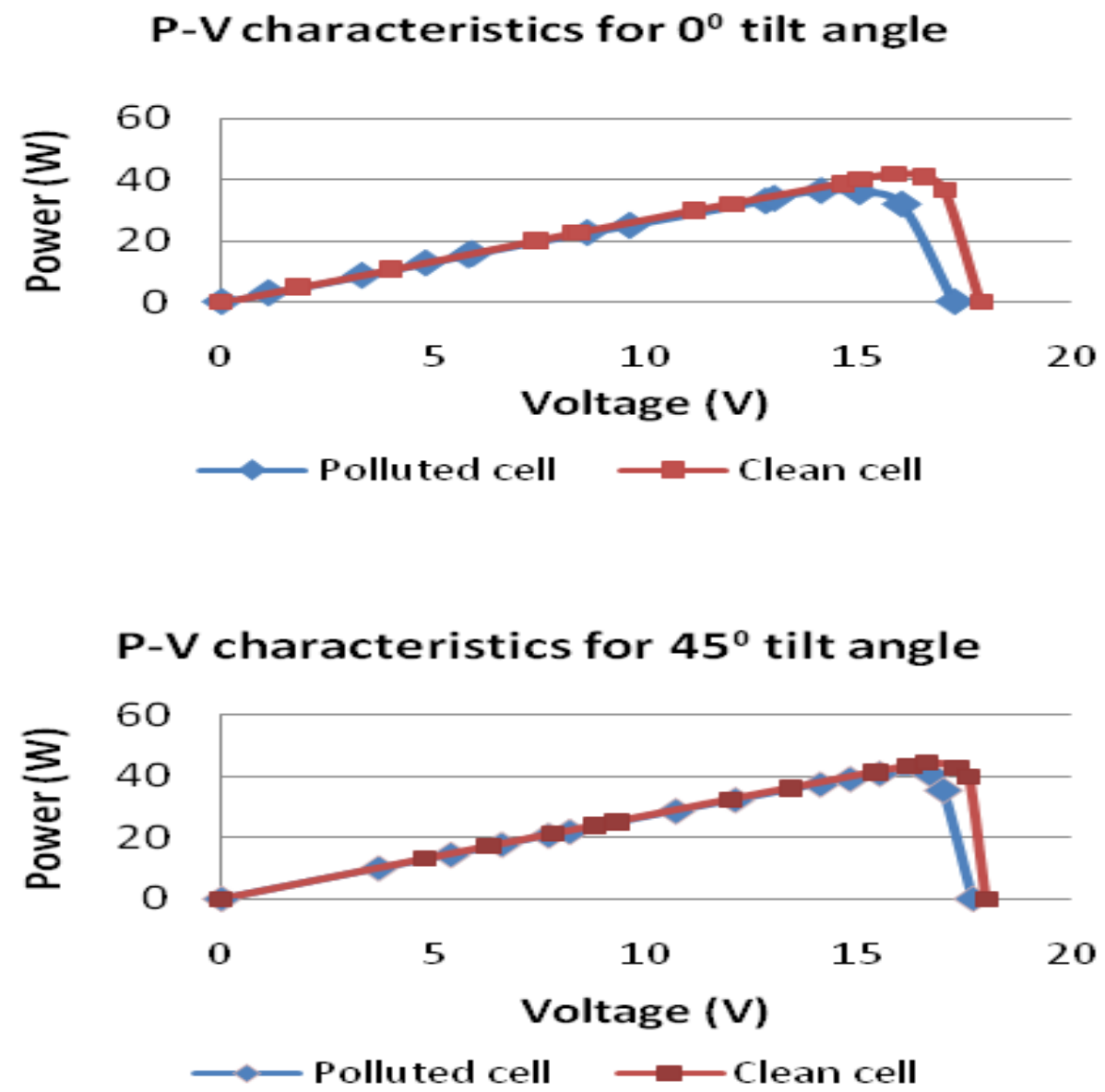

Fig. 9. The resulted power vs. voltage for the measured PV cells with load (for $0^{\circ}$ and $45^{\circ}$ tilt angle)

Table 3

Open circuit voltages and differences in \% for each tilt angle

\begin{tabular}{l|ccccc|ccccc|ccccc}
\hline \hline \multicolumn{1}{c|}{} & \multicolumn{5}{|c|}{ Time 11:00 } & \multicolumn{5}{c|}{ Time 13:30 } & \multicolumn{4}{c}{ Time 14:45 } \\
\hline \multicolumn{1}{c|}{ Angle } & 0 & 30 & 45 & 60 & 90 & 0 & 30 & 45 & 60 & 90 & 0 & 30 & 45 & 60 & 90 \\
Polluted (V) & 18 & 18.24 & 19.5 & 19.59 & 19.77 & 18.3 & 19.11 & 19.59 & 19.77 & 19.47 & 15.12 & 17.91 & 19.29 & 19.65 & 19.32 \\
Clean (V) & 19.14 & 19.35 & 19.71 & 19.8 & 19.98 & 18.87 & 19.65 & 20.01 & 20.1 & 19.77 & 17.22 & 18.81 & 19.8 & 20.16 & 19.8 \\
Difference \% & 5.96 & 5.74 & 1.07 & 1.06 & 1.05 & 3.02 & 2.75 & 2.10 & 1.64 & 1.52 & 12.20 & 4.78 & 2.58 & 2.53 & 2.42 \\
\hline \hline
\end{tabular}

Table 4

Open circuit voltages for each tilt angle

\begin{tabular}{c|ccccc|ccccc}
\hline$U_{o c}$ & \multicolumn{9}{|c|}{ Polluted } & \multicolumn{5}{c}{ Clean } \\
\hline Timelangle & 0 & 30 & 45 & 60 & 90 & 0 & 30 & 45 & 60 & 90 \\
$11: 00$ & 18 & 18.24 & 19.5 & 19.59 & 19.77 & 19.14 & 19.35 & 19.71 & 19.8 & 19.98 \\
$13: 30$ & 18.3 & 19.11 & 19.59 & 19.77 & 19.47 & 18.87 & 19.65 & 20.01 & 20.1 & 19.77 \\
$14: 45$ & 15.12 & 17.91 & 19.29 & 19.65 & 19.32 & 17.22 & 18.81 & 19.8 & 20.16 & 19.8 \\
\hline \hline
\end{tabular}


Table 5

Short circuit current and differences in \% for each tilt angle

\begin{tabular}{lccccc}
\hline \hline \multicolumn{1}{c}{$I_{s c}$} & \multicolumn{5}{c}{ Time 11:30 } \\
\multicolumn{1}{c}{ Angle } & 0 & 30 & 45 & 60 & 90 \\
\hline Polluted (A) & 2.631 & 2.67 & 2.7 & 2.724 & 2.757 \\
Clean (A) & 2.703 & 2.721 & 2.739 & 2.763 & 2.79 \\
Difference \% & 2.66 & 1.87 & 1.42 & 1.41 & 1.18 \\
\hline \hline
\end{tabular}

\section{CONCLUSION}

The experimental tests are conducted with the group of 10 photovoltaic panels installed on the roof of the building of the Electrical Engineering Faculty resided on the Polytechnic University of Tirana. Clean and polluted photovoltaic panels are monitored for each tilt angle, respectively $0^{\circ}, 30^{\circ}, 45^{\circ}$, $60^{\circ}$ and $90^{\circ}$. The results show a rise in efficiency for the cleaned panel for each tilt angle. But the biggest difference in performance occurs for $0^{\circ}$ angle, while the smallest one for $90^{\circ}$ angle.

From the calculations it turns out that the difference in relation to the maximum power $\left(P_{\max }\right)$ for the $0^{\circ}$ tilt angle is $12.9 \%$, whereas for the $45^{\circ}$ is $8 \%$.

The pollution also affects the open circuit voltage and short circuit current values. So from the values obtained, a rise of up to $12.2 \%$ of the $U_{o c}$ for the cleared panel with the $0^{\circ}$ angle is seen. And the effect comes and decreases with the angle increase (where the smallest impact is on $90^{\circ}$ angle).

The same thing can be said about the short circuit current $I_{s c}$. For $0^{\circ}$ tilt angle the difference is $2.66 \%$, while for $90^{\circ}$ the difference is $1.18 \%$.

This paper clearly shows the importance of cleaning and maintenance of photovoltaic panels to maximize their efficiency.

\section{REFERENCES}

[1] Tian, W., Wang, Y., Ren, J., Zhu, L.: Effect of urban climate on building integrated photovoltaics performance. Energy Conversion and Management, vol. 48 (1), pp. 1-8, (2007).

[2] Kaldellis, J. K., Kokala, A.: Quantifying the Decrease of the Photovoltaic Panels' Energy Yield Due to Phenomena of Natural Air Pollution Disposal, Energy, vol. 35, pp. 4862-4869, (2010).

[3] Betul Bektas Ekici: Variation of photovoltaic system performance due to climatic and geographical conditions in Turkey, Turk J Elec Eng \& Comp Sci, Vol. 24, Num. 6, pp. 4693-4706 (2016).

[4] SunPower Limited Product and Power Warranty for PV Modules, Sun Power ${ }^{\circledR}$, July 2010.

[5] Miqdam T. Chaichan, Bashar A. Mohammed, Hussein A. Kazem: Effect of pollution and cleaning on photovoltaic performance based on experimental study, International Journal of Scientific \& Engineering Research, Vol. 6, Issue 4, pp. 594-601 (2015).

[6] Cano, J.: Photovoltaic Modules: Effect of Tilt Angle on Soiling, Master thesis, Arizona State University: August 2011.

[7] AlAiawy, I. T.: Wind and other factor requrements to solar energy applications in Iraq, Solar and Wind Technology, vol. 7, pp. 597-600 (1990).

[8] Mani, M. and Pillai, R.: Impact of dust on solar photovoltaic (PV) performance: Research status, challenges and recommendations, Renewable Sustainable Energy Rev., vol. 14, pp. 3124-3131 (2010).

[9] John, J. J.: Characterization of Soiling Loss on Photovoltaic Modules, and Development of a Novel Cleaning System, Ph.D. Thesis, Department of Electrical Engineering, Indian Institute of Technology Bombay, 2015

[10] www.geo.edu.al/site/, Institute of GeoSciences, Energy, Water and Enviroment, 2015.

[11] Laudani, A., Fulginei, F. R., Salvini, A.: Identification of the one-diode model for photovoltaic modules from datasheet values. Sol Energy, vol 108, pp. 432-446 (2014).

[12] Guide to Interpreting I-V Curve Measurements of PV Arrays, Solmetric Corporation, 2010.

[13] Pantić, Lana S., Pavlović, Tomislav M.: Determination of physical characteristics of horizontally positioned solar module in real climate conditions in Niš, Serbia, Physics, Chemistry and Technology, vol. 14, No 1, pp. 37-51 (2016). 